\title{
Integration of the fibrous feed improvement methods in the feeding systems in Asia as influenced by socio economical aspects
}

\author{
F Dolberg \\ Associate Professor (external), University of Aarhus, Department of Political Science, 8000 Aarhus C, Denmark
}

\begin{abstract}
Summary - The objective of the paper is to discuss some of the aspects related to adoption rates of fibrous feed improvement methods in Asian feeding systems, principally those influenced by socio-economic factors. Following a description of the circumstances in which uptake have taken place, the paper identifies strong institutional support in the form of well functioning extension, marketing and credit services as pre-conditions for uptake. Lack of research with a farmer (problem-led research) perspective is another constraint.
\end{abstract}

\section{Introduction}

Kossila (1984) estimated that in 1981 there were $2070 \mathrm{~kg} \mathrm{DM} /$ livestock unit of all fibrous crop residues in Africa and $2950 \mathrm{~kg}$ in Asia. Earlier, Jackson (1978) in his report to FAO had stressed that alkali treated fibrous crop residues can replace hay or silage provided they are adequately supplemented with oil meals. Jackson also recommended village trials were undertaken in order to determine the benefits of alkali treatment of straw in physical and economic terms.

Subsequently, a considerable effort has been put into crop residue research. Thus, Devendra (1991) estimated 28 meetings had been conducted in Asia in 17 years and yet farmer uptake was limited. The objective of the paper is to discuss some of the reasons for this situation.

\section{Characteristics of crop residues}

Preston and Leng (1987) have provided the following general characteristic of fibrous crop residues:

. they are low in nitrogen content

- they are composed of cell wall components with little soluble cell contents and therefore have to be digested by rumen fermentation.

However, these properties are also typical of many tropical grasses.

\section{Methods to enhance fibrous crop residue utilization}

Several approaches have been researched and technically the most promising are ureaammonia treatment (Doyle et al, 1986; Singh and Schiere, 1993), nitrogen supplementation by protein meals and various legumes (Preston and Leng, 1987), a urea-molasses block (Leng, 1983; Sansoucy, 1986), and surplus feeding, allowing the animals to select and reject feed (Owen, 1994).

\section{Features of the research results}

It is typical of the research results that only some are discoveries by scientists. Many findings can be classified as documentation of farmer practices. Alkali treatment and ureamolasses blocks are examples of scientist led discoveries and attempts are now made in several countries to introduce them. As a byproduct these efforts have draw attention to the potential benefits that may be obtained in pursuing further research in the area of variation in the quantity and quality of fibrous crop residues (Joshi et al, 1994). The work has also indicated that in very intensively cropped areas with little access to grazing, cattle have gone through a process of natural selection for high fibrous crop residue intake (Mould et al, 1982; Chowdhury, personal communication).

Other areas, which in recent years have received much research attention are the concept of luxury or surplus feeding, which allows the animal to select for the most nutritious parts; protein meal or "bypass" protein supplementation and supplementation of fibrous crop residues with legumes to stimulate rumen function (Silva and Orskov, 1985; Preston and Leng, 1987). Luxury or surplus feeding allows the animal to select the most nutritious parts of the plant (Owen, 1994) 
and surveys in India have shown that in dry regions the value of the sorghum stover in such a traditional feeding system can almost equal that of grain and in very dry years have higher value (Kelley et al, 1991).

While Preston and Leng (1987) presented the general principles to follow in nutritional terms for feeding of fibrous crop residues, several cases can be cited to prove that most of them contain strong elements of traditional farmer practices. Thus, it is a common routine in many countries to allow ruminants to graze cereal fields after harvest, permitting the animals to do selective eating. Likewise it is common farmer practice in many countries to supplement stalifed animals some high protein meals and green grass or legumes to the bulk of fibrous crop residue feed.

It is thus concluded that whatever promising technologies scientists have discovered in recent years have strong components of traditional farmer practices.

\section{Characteristics of uptake}

While farmers in some parts of the World for generations have practised some of the technologies now advocated, uptake has not been as expected of some of the science driven technologies.

However, where uptake has taken place to any significant extent, political and institutional support have typically been strong.

\section{Ammonia treatment in China}

Starting in the middle of the nineteen eighties, China supported by FAO has undertaken work on ammoniation of fibrous crop residues. In 1995 Tingshuang (personal communication) reported 16 million tonnes were treated on 7 million small farms, mainly by application of the urea-ammonia technology (Dolberg and Finlayson, 1995). It was shown that already in 1992 nearly three times more cattle were marketed for slaughter from Henan, one of the project provinces with intensive wheat, maize and cotton production, in comparison to the pastures of Inner Mongolia.

Strong government support, plenty of crop residues with practically zero opportunity cost, presence of an extension service, on-farm trials and conducive prices (Dolberg and Finlayson, 1995) are important factors explaining uptake.

\section{Urea-molasses block and bypass protein work}

The National Dairy Development Board of India has undertaken considerable work to introduce both the urea-molasses block and "bypass" protein meals to its five million milk producers and village trials have demonstrated nutritional benefits in milking animals (Garg, 1991). However, process of manufacture and plant cost have continued to occupy the attention of scientists, although it is now expected a cold process (Sansoucy, 1986) conducted in a cheap plant will take the process forward (Garg, personal communication) as it avoids the cost associated with heating.

Supplementation of basal diets of crop residues with protein from an oilcake (expected to partly escape rumen fermentation) is essential and there are large responses to small supplements (Table I) as demonstrated in recent data from China.

On-farm trials in Mauritius (Boodoo et al, 1991) in which sugarcane tops constituted the basal diet demonstrated that a supplement of $0.25 \mathrm{~kg}$ cottonseed cake plus minerals were comparable to $0.50 \mathrm{~kg}$ of a concentrate mixture consisting of wheat bran $5 \%$, rice bran $11.5 \%$, maize $20 \%$, cottonseed cake (or groundnut cake) $30 \%$, molasses $30 \%$, common salt $1 \%$ and calcium carbonate $2.5 \%$ per $\mathrm{kg}$ of milk in terms of milk yields (approx. $2850 \mathrm{~kg}$ milk/lactation) and cow fertility. However, such trials have not been undertaken with alkali treated or untreated straws and stovers fed to milking cows and makes the foundation for practical recommendations to farmers weak.

\section{Treated straw in India and Bangladesh}

A considerable number of on-farm trials have been conducted in India with urea-ammonia treatment of fibrous crop residues (Singh and Schiere, 1993, 1994 and 1995) and the emerging conclusion is that the relevance of the technology is in areas with no space for green fodder production, but for moderate to good potential for milk production in the animals. However, in general terms uptake has been sporadic and not on any large scale. It is possible there are socio-economic reasons for this as for example in the gender division of labour, that has not received sufficient attention so far in crop residue research. 


\section{Gender}

The gender aspects have been dealt with in a report from India (Muylwijk, 1994).

Studies were undertaken at sites where the technology had been introduced on-farms. In the state of West Bengal, the following gender division of work was noticed (Table II).

The same work (Muylwijk, 1994) points at some problem areas, which have not received much research attention in the particular example resulting in wrong extension messages. Thus, it is reported how the technology is restricted to dry areas and seasons as it is mentioned straw has to be dry before treatment to avoid losses due to fung and mould. This statement lacks appreciation of the technical fact that urea-ammonia treatment actually can be used to preserve wet straw and therefore ought to have particular relevance in wet regions and seasons as a method of preservation. However, this aspect has only recently (Chowdhury and Huque, unpublished data) received research attention.

It was further noted that fodder shortage was greatest during harvest, when people are busy. When income is controlled by the husbands, women may not feel any incentive to put in the extra labour. Some women also mentioned that treated straw resulted in a looser dung, which is less suitable for dung cakes, traditionally used as fuel.

Women in the North Indian state of Haryana reported much less problems with treated straw and were generally enthusiastic about the technology (Muylwick, 1994) leaving the impression that inadequate extension effort was the main reason for lack of adoption of the technology.

The study showed that small farmers wives were the group with highest interest in the technology as the wives of rich farmers do not generally tend to animals, while many landless women have no access to straw both due to high cost involved in acquiring straw and to lack of space to do the treatment.

\section{Bangladesh}

In the early nineteen eighties a considerable amount of work on the urea-ammoniation technology was undertaken in Bangladesh (Saadullah, 1984), but uptake has been disappointing (Dolberg, 1992).

However, in recent years innovative credit programmes undertaken by NGOs for landless people and small farmers in Bangladesh (Fuglesang and Chandler, 1993) have lifted an

Table I. Effect of supplementing protein to ammonia treated wheat straw in China (Dolberg and Finlayson, 1995)

$\begin{array}{lllllll}\text { Cottonseed cake kg } & 0.00 & 0.25 & 0.50 & 1.50 & 2.00 & 2.50 \\ \text { Number of animals } & 8 & 8 & 8 & 8 & 8 & 8 \\ \text { Initial weight kg } & 137 & 159 & 183 & 192 & 175 & 194 \\ \text { Final weight kg } & 143 & 193 & 231 & 263 & 250 & 274 \\ \text { Daily gain, g } & 63 & 370 & 529 & 781 & 829 & 892 \\ \begin{array}{l}\text { D.M. int.,\% of live wt.: } \\ \text { Straw }\end{array} & 2.7 & 2.5 & 2.3 & 2.0 & 1.8 & 1.7 \\ \text { Cottonseed cake } & 0.0 & 0.1 & 0.2 & 0.5 & 0.8 & 0.9 \\ \text { Total } & 2.7 & 2.6 & 2.5 & 2.5 & 2.6 & 2.6 \\ \text { F.C.R. } & 60 & 12 & 10 & 7 & 7 & 7\end{array}$

Table II. Gender division in straw treatment (Muylwijk, 1994)

Type of work

carry straw

carry water

urea and water mixing

sprinkling of solution

trampling
Done by

$\begin{array}{ll}\text { women } & \text { men } \\ \mathrm{x} & \\ \mathrm{x} & \mathrm{x} \\ \mathrm{x} & \mathrm{x} \\ \mathrm{x} & \mathrm{x}\end{array}$


important constraint for them and it has meant that both the urea-ammonia treatment and the urea-molasses technology are now finding uptake in the country. Thus a recent survey (Saadullah et al, unpublished data) showed 73 per cent of the farmers applying one of the technologies had obtained loans in the US dollar 50 - 100 interval per farmer.

\section{Preconditions for uptake}

Two factors present themselves as important for uptake or lack of it.

\section{Institutional support}

Where available technologies are fitting and have been adopted, it can be concluded that the institutional support has been strong such as in China, the National Dairy Development Board of India and the NGOs in Bangladesh. As livestock extension services in developing countries are weak as a rule, this may constitute an important part of the explanation for the lack of adoption.

\section{Lack of problem-led research}

However, the question also needs to be asked, whether research has been sufficiently relevant. There is very little work reported in areas such as preservation of wet straw (Chowdhury and Huque, unpublished data) overcoming animal feeding labour constraints during harvest and women's problems of dung cake manufacture from loose dung or treatment of straw in homesteads with limited space, just to mentioned some of problems reported from the field.

Therefore a general lack of problem-led research is seen as an important factor explaining - after all - limited uptake.

\section{Direction of future work}

In the second part of the paper some ideas are presented concerning the strategy and direction of future work.

\section{Towards a framework for farmer focused research}

It is thought provoking to reflect on the fact that technologies beginning to find uptake among small farmers in developing countries such as "bypass" protein and surplus fibrous crop residue feeding, in fact are well established old farmer practices to which a scientific understanding now has been added.

Restricted suckling (Preston and Leng, $1987)$ is another example to mention.

It therefore seems obvious to suggest that to fully exploit the potential small farmers possess for increased animal production, more work is required to scientifically describe and understand their current practices and to test new ones under their conditions.

\section{Interaction for technology research and development}

Generating much feedback from farmers and deal with it constructively is, according to Bunch (1982), a most important condition for success, although, however, it has been difficult to put into practice (Merrill-Sands and McAllister, 1989). However, in the author's experience, the following procedure is a way ahead.

Identification of strengths and weaknesses Instead of the conventional sequence of event : ufrom laboratory to research station to farmer testing to wide-scale application through the extension system", it is argued that early in the technology research and development phase it is important to get out and make a test on-farm. Not so much to promote the technology as for the project planners and scientists to learn about weak and strong points of the technology and project design. It is an iterative process, and it is important to stress this is a learning phase (Chambers, 1993) for the planners, project personnel, scientists and farmers alike. It is argued that if more technologies claimed to be ready on the shelf for extension were subjected to this test, it would be realised that many of them are in fact not ready and, logically, project planning would become more realistic.

\section{Expansion of methodological tool kit}

A further important reason to get out on farms is to develop and improve researchers' awareness of the methods for data collection and analyses, which can be applied under these conditions.

Assuming some researcher creativity, 
bringing more of them out to work with farmers is expected to foster consciousness of many more analytical methods to apply.

There is a particular lack of information of appropriate experimental methodology for the evaluation of integrated systems dealing with multiple inputs and outputs, which modern statistical science according to Riley (1995) is quite capable of addressing.

\section{Creation of a farmer $x$ extension $x$ scientist alliance}

If successful, it is likely the iterative process outlined above has identified leaders at farmer, extensionist and scientist levels, who by joining forces can do the necessary research and development of the technology in situ. The approach is still sparsely used, but teams using it can reinforce each other by communicating with collegial groups elsewhere in the World through modern means of communication (Speedy, 1993). By offering scholarships to host country students (Dolberg, 1991), projects can meet several objectives at one time: baseline data can be collected, ongoing monitoring and evaluation can be conducted and future scientists and extensionists can be trained.

In the words of Biggs (1995) the basic problem may be that this coalition so far is too weak to generate the impact the approach promises. But the alternative is certainly available for decision-makers to support and some of the most promising work is conducted by non-governmental organisations (Farrington et al, 1993).

\section{Conclusion}

Many research findings of relevance to small farmers contain strong elements of indigenous knowledge and only a few can be described as pure scientific discoveries. Limited uptake of fibrous crop residue technologies is ascribed to lack of problem led research and weak livestock extension services.

Where uptake has taken place this has been associated with one of the following ingredients: strong institutional support to extension service, milk marketing and credit for landless and small farmers. However, institutions capable of conducting such work in an effective manner on a large scale are still very limited in developing countries.
In future, research should to a much greater extent start by involving farmers, generate feedback from farmers and let this feedback serve as a foundation - in parallel with the standard literature review - for definition of research problems.

A small start has merit with regard to testing and large-scale application of a technology. It is a means to identify farmers, researchers and extensionists with a natural talent for the work and such people are critical for future expansion of rural livestock production.

When such people - and institutions - are identified on-farm work will accelerate the research process and make it move faster than if the scientists confined themselves to the research station and laboratory. If the technology is a failure, it is easier to redirect or close down a small than big project.

An important condition for success of that approach is that the leading scientists take it serious and are prepared to spent time in the field with farmers, demonstrating to their juniors how to deal with feedback from farmers and convert that into researchable problems, leading to scientific publications and promotions comparable to laboratory and onstation work.

\section{Literature cited}

Biggs SD (1995) Participatory technology development: Reflections on current advocacy and past technology development. In: Participatory technology development workshop on The Limits of Participation, intermediate Technology, Inst Educ, Bedford Way, London, 1-10

Boodoo AA, Ramjee R, Hulman B, Dolberg F, Rowe JB (1990) Effects of supplements of balanced concentrates and cottonseed cake on animal production in Mauritian villages. Livestock Res Rural Dev 2, 1, 8-16

Bunch R (1982) Two ears of corn - A guide to peoplecentered agricultural improvement. World Neighbors USA, $247 p$

Chambers R (1993) Challenging the professions. Frontiers for Rural Development, Intermediate Techn Publ, 76-88

Dolberg $F$ (1991) Adding a learning to a blueprint approach - or What a small amount of flexible money can do -. Livestock Res for Rural Dev 3, 1 , $1-10$

Dolberg F (1992) Progress in the utilization of ureaammonia treated crop residues : biological and 
socio-economic aspects of animal production and application of the technology on small farms Livestock Res Rural Dev 4, 2, 20-31

Dolberg F, Finlayson P (1995) Treated straw for beef production in China. World Anim Rev FAO, 82 , 14-24

Doyle PT, Devendra C, Pearce GR (1986) Rice straw as a feed for ruminants. Intern Dev Prog of Austr Univ and Colleges Ltd, $117 \mathrm{p}$

Farrington $\mathrm{J}$, Bebbington A, Wellard $\mathrm{K}$, Lewis D (1993) Reluctant partners? Non-governmental organizations, the state and sustainable agricultural development. Routledge, $195 \mathrm{p}$

Fuglesang A, Chandler D (1993) Participation as process - Process as growth. Grameen Trust, Dhaka, Bangladesh. $281 \mathrm{p}$

Garg MR (1991) Urea-molasses feeding in India. In: Reg Workshop on Increasing livestock production through better utilization of avallable feed resources, National Dairy Development Board, India, 1-18

Jackson MG (1978) Treating straw for animal feeding. Anim Prod and Health 10, FAO, $68 \mathrm{p}$

Joshi AL, Doyle PT, Oosting SJ, (1994) Variation in the quantity and quality of fibrous crop residues. Indian Council of Agric Res, New Delhi, BAIF Deve Res Foundation, Pune, India and Dept of Trop Anim Prod, Agric Univ, Wageningen, Netherlands, $171 \mathrm{p}$

Kelley TG, Rao PP, Walker TS (1991) The relative value of cereal straw fodder in the Semi-Arid tropics of India : Implications for cereal breeding Programs at ICRISAT. Resource Manage Program. Economics Group Progress Report 105, Intern Crops Res Inst for the Semi-Arid Tropics, India, $33 p$

Kossila VL (1984) Location and potential feed use. In Straw and other fibrous By-products as feed, (Sundstol F, Owen E, eds), Elsevier, 4-24

Leng RA (1983) The potential of solidified molassesbased blocks for the correction of multinutritional deficiencies in buffalos and other ruminants fed low quality agro-industrial by-products. In: The use of nuclear techniques to improve domestic buffalo production in Asia. Intern Atomic Energy Agency, Vienna, 135-150

Merrill-Sands D, Mc Allister J (1989) Strengthening the integration of on-farm client-oriented research and experiment station research in national agricultural research systems (NARS): Management lessons from nine country case studies, OFCOR Comparative Study Paper 1 , intern Serv for Nat Agric Res, Netherlands, $60 \mathrm{p}$
Mould FL, Saadullah M, Haque M, Davis C, Dolberg $F$, Orskov ER (1982) Investigation of some of the physiological factors influencing intake and digestion of rice straw by native cattle of Bangladesh. Trop Anim Prod 7, 3, 174-181

Muylwijk J (1994) Third gender consultancy and Workshop Report CB56. Departments of Tropical Animal Production and Gender Studies, Agri Univ, Wageningen, Netherlands, $37 p$

Owen $E$ (1994) Cereal crop residues as feed for goats and sheep. Livestock Res Rural Dev 6, 1, 47-61

Preston TR, Leng RA (1987) Matching ruminant production systems with available resources in the Tropics and Sub-Tropics. Armidale, Australia, Penambul Books, $245 \mathrm{p}$

Riley J (1995) Multivariate environmental statistics Research institute and field investigations. Statistics Department, IACR-Rothamsted, Harpenden, U K (in press)

Saadullah M (1984) Supplementing ammoniated rice straw for native cattle in Bangladesh. Royal Veter and Agric Univ, Denmark, 136 p, (Ph D thesis)

Sansoucy R (1986) The Sahel: Manufacture of molasses-urea blocks. World Animal Review FAO, 57, 40-48

Silva AT, Ørskov ER (1985) Effect of unmolassed sugar beet pulp on the rate of straw degradation in the rumens of sheep given barley straw. Proc Nutri Soc 44, 50A

Singh K, Schiere JB (1993) Feeding of ruminants on fibrous crop residues. Aspects of treatment, feeding, nutrient evaluation, research and extension. Indian Council of Agricultural Research, New Delhi, India and Dept.of Tropical Animal Production, Agric Univ, Wageningen, Netherlands, $476 \mathrm{p}$

Singh K, Schiere JB (1994) Variation in the quantity and quality of fibrous crop residues. Indian Council of Agric Res, New Delhi, BAIF Dev Res Foundation, Pune, India and Dept.of Tropical Anim Prod, Agric Univ, Wageningen, Netherlands, $171 p$

Sing K, Schiere JB (1995) Farming systems research for improving livestock production and crop residue utilization. Indian Council of Agric Res, New Delhi, Nat Dairy Res Inst ,Karnal (Haryana), India and Dept.of Trop Anim Prod, Agric Univ, Wageningen, Netherlands, $162 \mathrm{p}$

Speedy A (1993) Electronic communication for development.In: Democratizing development (Dolberg F, ed) Dept of Pol Sci, Univ of Aarhus, Denmark, 55-75 